\section{Category}

Organo- and

Biocatalysis

\section{Key words}

Knoevenagel condensation

iminium ion catalysis

aminocatalysis

$\alpha, \beta$-unsaturated esters

\section{Synfact}

E. KNOEVENAGEL* (UNIVERSITÄT HEIDELBERG, GERMANY)

Über eine Darstellungsweise des Benzylidenacetessigesters

Ber. Dtsch. Chem. Ges. 1896, 29, 172-174.

Über den Chemismus der condensierenden Wirkung des Ammoniaks und organischer Amine bei Reactionen zwischen Aldehyden und Acetessigester

Ber. Dtsch. Chem. Ges. 1898, 31, 738-748.

Condensation zwischen Malonester und Aldehyden unter dem Einfluss von Ammoniak und organischen Aminen Ber. Dtsch. Chem. Ges. 1898, 31, 2585-2595.

Condensation von Malonsäure mit aromatischen Aldehyden durch Ammoniak und Amine

Ber. Dtsch. Chem. Ges. 1898, 31, 2596-2619.

\title{
The Knoevenagel Condensation
}

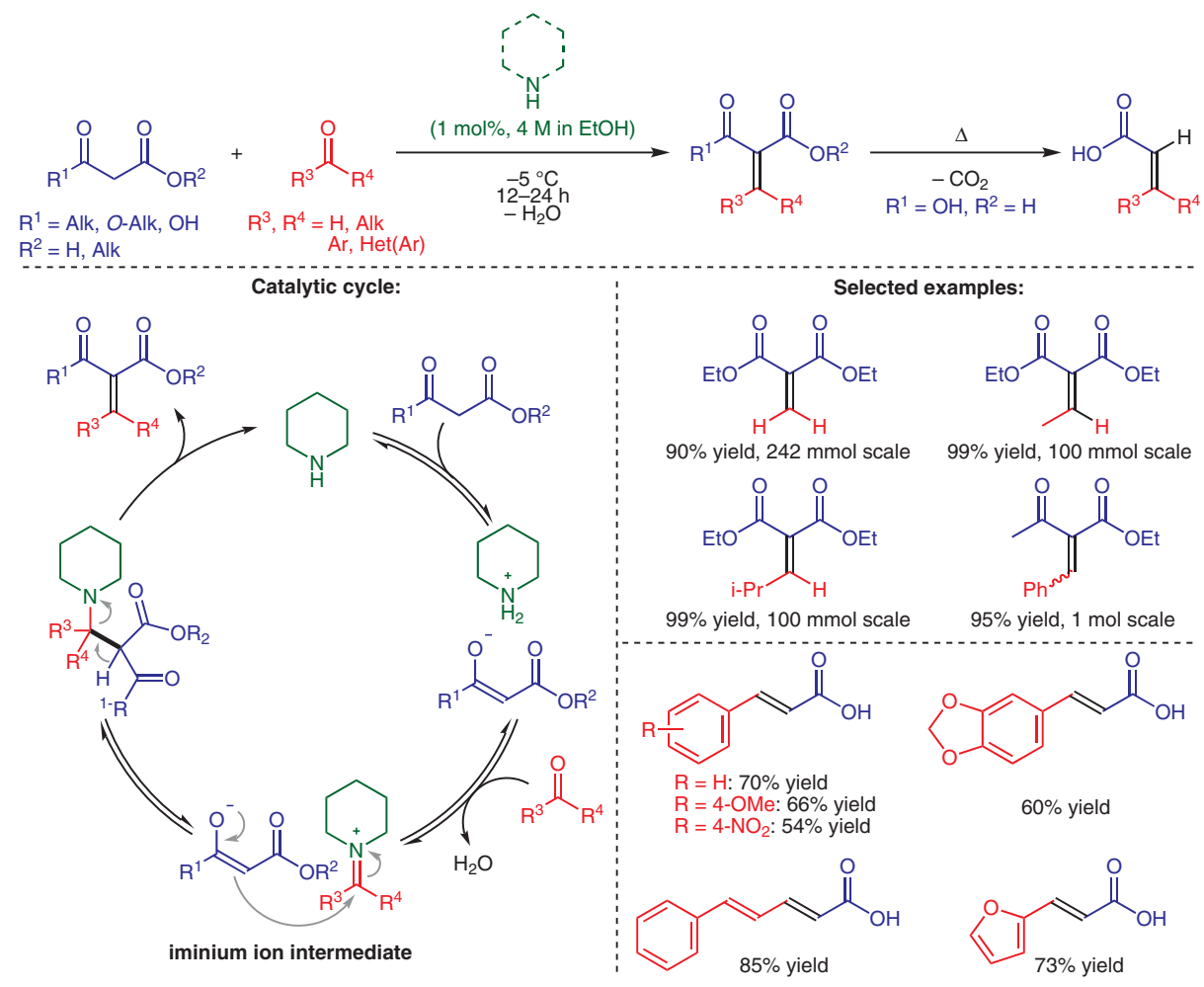

Significance: Between 1896 and 1898, Emil Knoevenagel reported that primary and secondary amines, their respective salts, and ammonia (but not tertiary amines) are efficient catalysts for the aldol condensation of $\beta$-keto esters or malonates with either aldehydes or ketones. The reaction proceeds under mild conditions, is scalable, tolerates a wide range of substrates, and delivers the corresponding $\alpha, \beta$-unsaturated esters in good to excellent yields in an atom-economic fashion. Decarboxylation of malonic acid-derived products selectively provides $(E)$-cinnamic acid derivatives.
Comment: More than 120 years ago, Knoevenagel had already recognized the catalytic nature of the added amine. His discovery therefore arguably signifies the starting point of aminocatalysis. The proposal of iminium-type intermediates (Schiff'sche Körper or Schiff-type intermediates) had a great influence on later studies that ultimately led to the systematic development of aminocatalysis. As the Knoevenagel condensation is a reliable, efficient, and scalable method for the formation of $\mathrm{C}-\mathrm{C}$ bonds, it is still widely used in both academia and industry. 